\title{
MACHADO DE ASSIS E O MITO DE APOLO*
}

\section{FRANCISCO DE ASSIS BARBOSA}

\section{Apresentação de Hélio de Seixas Guimarães}

Resumo: $\mathrm{O}$ artigo propõe que o ideal e os dons apolíneos teriam norteado a existência e a trajetória literária de Machado de Assis, em oposição ao mito dionisíaco, que teria guiado Lima Barreto.

Palavras-chave: Machado de Assis; Lima Barreto; discriminação racial.

\section{MACHADO DE ASSIS AND THE MYTH OF APOLLO}

Abstract: The article proposes that Machado's life and literary career were guided by Apollonian ideals that stand in perfect opposition to the Dyonisiac mith that would have led Lima Barreto.

Keywords: Machado de Assis; Lima Barreto; racial discrimination.

\section{APRESENTAÇÃO: MACHADO E LIMA NA ENCRUZILHADA DE FRANCISCO DE ASSIS BARBOSA}

0 jornalista, biógrafo, historiador e ensaísta Francisco de Assis Barbosa é o homenageado deste número na seção "Da tradição crítica". Nada seria mais adequado para uma edição que traz um dossiê Machado/Lima. 0 grande biógrafo, autor da monumental $A$ vida de Lima Barreto, nutriu e expressou admiração pela figura e pela obra machadianas ao longo de toda a vida.

* Barbosa, Francisco de Assis. "Machado de Assis e o mito de Apolo". Revista Brasileira, Rio de Janeiro, ano IX, n. 23-24, jul.-dez. 1958 (publicada em mar. 1959), p. 81-101. 
Os registros dessa admiração têm como marco inicial o mês de fevereiro de 1937. Poucos meses depois do aparecimento de Machado de Assis - estudo crítico e biográfico, de Lúcia Miguel Pereira, Barbosa publicou no Boletim de Ariel um artigo sobre o lançamento do livro, considerado por ele um dos mais importantes de 1936, ao lado de Sobrados e mucambos, de Gilberto Freyre. Os elogios ao feito de Lúcia Miguel Pereira, em cujo livro via também o talento da ficcionista que a biógrafa de fato se tornaria, culminavam como uma constatação: "a biografia do homem caramujo não é impossível". Teria o jovem de 23 anos recém completados começado a ruminar ali a possibilidade de escrever biografias?

0 que sabemos é que $A$ vida de Lima Barreto só seria publicada em 1952, mantendo-se até hoje, mais de sessenta anos depois, como a biografia mais completa escrita sobre 0 autor de Triste fim de Policarpo Quaresma. Nela, a vida e a obra de Machado de Assis se fazem presentes em vários trechos e referências. Barbosa teve papel importante também na edição da obra de Lima. Com Antonio Houaiss e M. Cavalcanti Proença, dedicou-se a compilar, anotar e estabelecer o texto para a edição das Obras completas de Lima Barreto.

A intensa e extensa dedicação a Lima Barreto a partir da década de 1950 não impediu que Barbosa encontrasse oportunidades para tratar de Machado.

Em "Romance, novela e conto no Brasil", um ensaio longo e panorâmico sobre a prosa no Brasil, salienta a obra de Machado, comparando-o a "uma ilha na paisagem literária brasileira", por ter se destacado "singularmente dos prosadores do seu tempo, conseguindo elevar o romance brasileiro a uma altura jamais atingida e até hoje inigualada". Em 1971, prefaciou um volume de contos de Machado de Assis organizado por Hercílio Ângelo, e prefaciou também a edição crítica de Esaú e Jacó, lançada pelo MEC/Civilização Brasileira em 1975. Além disso, fez várias palestras e publicou também diversos artigos em jornais, entre eles "Machado, caminhos e viagens imaginárias", que saiu no Jornal do Brasil do Rio de Janeiro em 1974.

0 trabalho de maior fôlego dedicado a Machado, no entanto, foi o pequeno livro Machado de Assis em miniatura - um perfil biográfico, publicado em 1957, com segunda edição lançada em 2008 com apoio da Fundação Biblioteca Nacional. Como diz o próprio Barbosa em prefácio, não há ali nenhuma contribuição original; entretanto, ele produziu uma obra de divulgação da vida e obra de Machado a partir do que havia sido escrito de melhor na crítica e na biografia do escritor.

No texto que reproduzimos aqui, "Machado de Assis e o mito de Apolo", publicado pela primeira vez em 1958, vemos como foi longa a impressão causada pela leitura da biografia de Lúcia Miguel Pereira. Apoiando-se em material levantado pela biógrafa, bem como nas interpretações dela sobre a trajetória social do escritor, Barbosa propõe que dois mitos opostos norteiam a vida dos dois escritores. Para Machado, é o mito de Apolo que guia tanto o itinerário do escritor do morro do Livramento à Academia 
Brasileira de Letras como o seu estilo "claro, perfeito, apolíneo". Já Lima Barreto teria vivido sob o signo de Dionísio, com seu "trágico acento masoquista".

0 ensaio de Barbosa mantém sua atualidade e interesse também por chamar a atenção, já nos anos 50, para os modos como os dois escritores enfrentaram a discriminação de cor e raça, assunto de dois dos ensaios publicados nesta edição, "Machado de Assis and Brazilian literary independence: toward a postcolonial national aesthetic", de G. Reginald Daniel, e "Machado de Assis e o mulato de 'alma grega'”, de Terezinha V. Zimbrão da Silva.

Por tudo isso, não poderia ser mais justa e adequada esta pequena homenagem da Machado de Assis em linha ao grande amigo da literatura brasileira que foi Francisco de Assis Barbosa. A MAEL agradece publicamente a Maria Cristina Jardim Barbosa a permissão para publicar este artigo.

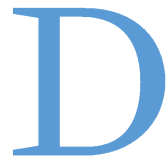

evo prevenir, desde logo, especialmente aos machadianos: não vou falar do escritor. Vou falar do homem Machado de Assis, embora seja difícil, quase impossível mesmo, separar um do outro - o artista do indivíduo. Explico-me: não tratarei dos livros, do romancista, do estilista, mas sim dos gestos, do comportamento, da atitude, enfim, do profissional das letras diante da vida. Quase que ia dizendo: falarei do artista, não falarei da sua arte.

A biografia de Machado de Assis, ainda não superada, foi escrita por delicada mão feminina, que lhe traçou o retrato, antes tão difuso, com inexcedível precisão e finura intelectual dignas do mestre. Retrato que é também uma análise de profundidade da complexa alma machadiana, que os estudos, dados ou informes posteriores só têm confirmado. De fato, pouco ou nada há a acrescentar ao notável estudo crítico e biográfico de Lúcia Miguel Pereira, no que diz respeito à interpretação do homem e do seu comportamento social.

Do escritor, ou melhor, do estilista, direi apenas que Machado de Assis pertence ao pequeno mundo dos que dominam a técnica literária em toda a sua plenitude. Foi um artesão completo. E que soube, como nenhum outro, fazer com as palavras o que bem quis. Tivesse refreado menos a imaginação, no que foi impedido pelo excesso de autocrítica - autocrítica que não é certamente a característica de grandes romancistas universais do porte de um Dickens, de um Balzac, de um Tolstoi, todos com a sua corcunda de folhetinista, algumas vezes folhetinista de gosto duvidoso - e o nosso Machado de Assis estaria certamente inscrito entre eles. A polícia que exerceu consigo mesmo, ao compor romances e contos, foi tão severa quanto 
a que se impôs a todos os atos da sua vida. Essa implacável autocrítica como que desvitaminizou o criador. $\mathrm{E}$ do homem forneceu a imagem estereotipada do acadêmico e do burocrata, respeitado e admirado por gregos e troianos, como se fosse uma relíquia de carne e osso, na impressionante unanimidade, ou quase unanimidade, dos seus contemporâneos, em que todos os credos e tendências se juntam num só coro de louvores.

Essa unanimidade provocaria um derrame de bílis de Sílvio Romero: o estudo infeliz, publicado em 1897, logo após a fundação da Academia, com ferinas alusões de ordem pessoal: "Ele gagueja no estilo, na palavra escrita, como outros na palavra falada". Mas todos sabemos que Sílvio Romero, prodigioso trabalhador intelectual, pesquisador e debatedor de ideias, não era lá muito forte em questões de estilo. Era esta precisamente a sua grande lacuna, conforme já o havia observado o próprio Machado de Assis, acrescentando: "Não me refiro às flores de ornamentação, à ginástica de palavras; refiro-me ao estilo, condição indispensável do escritor, indispensável à própria ciência - o estilo que ilumina as páginas de Renan e de Spencer, e que Wallace admira como uma das qualidades de Darwin."

Postumamente, é verdade, Machado de Assis teve alguns negadores, todos porém fora da literatura. Estranhos exemplos de marginais das letras, a blaterar no deserto o que chamam o estilo frouxo, árido, monótono, porque sem floreios, sem arroubos, sem dós de peito, do criador de Dom Casmurro. Mas esses exemplos - dois ou três não mais do que isso - não valem sequer para arranhar a glória do escritor, nem mesmo quebrar a unanimidade do julgamento. Citarei apenas um, como a mais expressiva de todas essas manifestações, assim mesmo pelo interesse sociológico que apresenta: a catilinária do prof. Hemetério José dos Santos, um mês depois da morte do escritor, negando o homem e a obra, de modo tão feroz e incompreensivo que só encontra justificativa numa explosão de recalque de quem, sendo negro, repudiava a consagração ao homem da mesma raça, mulato disfarçado, passando até por branco, que se libertara dos preconceitos em que o outro, sem poder esconder a cor, ainda se sentia escravizado.

Restrições como esta, de intelectuais de voo curto, explicam talvez aquele trecho do belo discurso de Olavo Bilac, proferido um ano após à morte de Machado de Assis, diante da placa comemorativa que a Academia Brasileira de Letras mandou colocar na casa da rua Cosme Velho onde morou o escritor e nela escreveu o mais importante da sua obra de romancista. "Não o compreendeu ainda todo o país - dizia o poeta - porque ele foi de algum modo um homem superior à sua época e ao seu meio; mas 
essa compreensão unânime há de vir com o tempo, com o aperfeiçoamento progressivo e fatal dos homens, com a fixação definitiva de uma cultura geral que já começa a afirmar-se". A casa foi demolida. A placa está hoje no Museu Histórico. Muito há ainda a fazer neste país, pela "fixação definitiva de uma cultura geral". Mas a verdade é que, cinquenta anos decorridos, participamos todos da "compreensão unânime" vaticinada por Bilac no seu discurso que termina com palavras que devem ser repetidas:

E há de o tempo morder e devorar esta placa de bronze; hão de as soalheiras e as chuvas arruinar e aluir esta casa; - mas, se um horroroso cataclismo social não dispersar esta nossa raça e não aniquilar a língua que falamos, a nossa romaria de hoje terá sido o início de uma glória perpétua.

Meio século depois, a placa e a romaria, a casa demolida e o antipático palacete erguido sobre os seus escombros parecem compor um apólogo machadiano em torno das homenagens póstumas, marcado não direi pelo sarcasmo mas pela ironia com que o mestre costumava perdoar os excessos do nosso temperamento tropical. Afinal de contas, como Bilac havia previsto, o tempo não "devorou" nem sequer "mordeu" a obra do escritor, antes venceu a displicência dos homens e tornou ainda maior a glória do romancista, do artesão admirável que ele foi, tanto na prosa como no verso.

Ao contrário do que pensava o prof. Hemetério José dos Santos, gramático empedernido, é precisamente no estilo que Machado de Assis se revela artista consumado. Se alguma restrição se lhe pode discutir não será no estilo em si mesmo, na sua carpintaria, no acabamento estético, mas na acomodação aos cânones consagrados do idioma, interrompendo assim as primeiras tentativas para a criação de um modo de escrever à brasileira - à americana, dizia-se na época - entrevista na obra de um Manuel Antônio de Almeida e de um José de Alencar. Escrevia como Frei Luís de Sousa e poetava como Camões, disse Rui Barbosa no elogio fúnebre à porta da Academia. De fato, ele não fez concessões, mantendo-se fiel à maneira tradicional de escrever à portuguesa. Verdade que enriqueceu a língua com muitas palavras novas, nascidas no Brasil, mas só transigiu no falar errado nos diálogos, assim mesmo através de certos personagens declaradamente incultos. Do mesmo truque estilístico se utilizaria depois um Monteiro Lobato no seu regionalismo, justapondo a fala do caipira em páginas de puro sabor lusitano, senão camiliano, tão do paladar do escritor paulista. 
Nesse acomodar o certo e o incorreto, como que definindo responsabilidades entre personagens sem cultura, e o próprio autor, cioso dos seus conhecimentos da língua, que é afinal uma das invenções de Machado de Assis, está toda a maneira de ser do escritor, toda a natureza do homem. As possíveis discussões de fundo, quase no sentido da aplicação da língua portuguesa nos trópicos, valorizam no entanto ainda mais a forma quase perfeita com que escreveu. Num estilo em que as palavras se encaixam com precisão matemática, deslizando sem tropeços, como as águas cristalinas de um regato - é evidente que a metáfora do rio ou da cachoeira não caberia no caso. No estilo claro, perfeito, apolíneo, em que está refletido o próprio ideal de Machado de Assis, ou melhor, servindo-me do vocabulário dos psicanalistas, a sublimação do mestiço de origem inferior, feio, gago, doente e pobre, marcado desde cedo pela vocação literária, e que, malgrado tantas condições negativas - sobretudo a pobreza e a cor -, tornou-se, afinal, um vitorioso, um homem-modelo não somente para a sua época, eivada de preconceitos, contra os mulatos ostensivamente mulatos, como nos dias de hoje, quando não desapareceram de todo as limitações dos negros, a ponto de existir uma lei - a Lei Afonso Arinos - classificando como delito contra a sociedade a discriminação racial.

A pobreza, Machado de Assis enfrentou-a com bravura. Não teve medo nem vergonha do trabalho. Menino, foi baleiro. Na adolescência e primeira mocidade, tipógrafo, empregado de livraria, revisor de provas. Mais tarde, jornalista e funcionário público. Soube construir assim, modesta mas solidamente, a base material que lhe permitiu a ascensão social, de moleque sem eira nem beira do morro do Livramento a ilustre morador do aristocrático bairro das Águas Férreas, de proletário humílimo a diretor de repartição e presidente da Academia Brasileira de Letras. Ascensão a que não faltou a nota burguesmente tranquila do casamento com mulher branca, bem-nascida, inteligente, culta, e que foi, durante mais de trinta anos, não apenas a companheira perfeita, como a enfermeira, a secretária, possivelmente a cozinheira de Machado de Assis. Cozinheira, sim, como ainda hoje é tão natural que o sejam as donas de casa brasileiras, notadamente as que fazem parte da classe média. Assim era o anjo tutelar de Machado de Assis, dona Carolina, ela mesma, a do soneto dos "pensamentos idos e vividos", a dona Carmo, a esposa suave e diligente, que tudo sabia prever para tudo prover, dotada do sexto sentido da arte de bem viver, fazendo os tapetes e as cortinas, com que enfeitava a casa, capaz de inventar, se preciso fosse, a "pobreza elegante", tal a sua sabedoria doméstica. 
A doença e a cor - outras barreiras que se antepunham à sua ascensão na sociedade - também as transporia Machado de Assis, nessa corrida de obstáculos que é a vida, para atingir a meta ambicionada, na idade madura, podendo gozar o triunfo, mesmo o aceitando com uma certa dose de ironia, sem virar a cabeça, mas ciente e consciente da paga que estava recebendo. No reconhecimento público da sua vitória, não faltaria, no crepúsculo da existência, uma coroa de louros a cingir-lhe a venerável cabeça, na tocante homenagem da entrega de um ramo do carvalho do Convento de Santo Onofre que abrigara o poeta Torquato Tasso, vindo da Itália com aquela comovente recomendação de Joaquim Nabuco, feita a Graça Aranha, a respeito do mestre querido: ele deve ser tratado com o mesmo carinho "com que no Oriente tratam as caravanas a palmeira, às vezes, solitária do oásis".

Palmeira solitária. Primus inter pares. Vencedor, e não vencido da vida, foi Machado de Assis. E vencedor que muito sofreu e muito lutou, sem no entanto apresentar, no fim da batalha, as cicatrizes de uma única falha de caráter, um deslize sequer de dignidade, uma escorregadela ainda que fugidia da compostura moral que sempre manteve em toda a sua vida exemplar. Dir-se-ia que viveu em permanente procura do equilíbrio do cotidiano, do mesmo modo que na arte sempre buscou a perfeição apolínea. Soube transigir, soube esperar, soube acomodar-se como homem e como escritor, sem no entanto ceder um milímetro no respeito para consigo mesmo. E tudo fez sem turbulência, nem espalhafatos. Apenas sendo fiel a si mesmo, sem trair a sua vocação literária, numa admirável lição de amor ao trabalho, de coerência, de perseverança, de honestidade.

A essa fidelidade a um ideal estético, esse constante desejo de harmonia, esse nunca desmentido anseio de beleza, no plano espiritual, como no simplesmente material da vida, da sua rotina doméstica, na luta para atingir a normalidade agradável de viver bem, de comer bem, de dormir bem, de viver, em suma, na plenitude da satisfação fisiológica, é que eu me permito discorrer sobre o "mito de Apolo", com a devida licença dos doutores da psicanálise, mito que parece ter iluminado toda a existência de Machado de Assis, no longo itinerário percorrido do miserável barraco do morro do Livramento ao confortável chalé da rua Cosme Velho.

Para frente, para cima. É como eu surpreendo os primeiros passos do menino, a caminho da escola pública, na rua do Costa ou na rua do Piolho, pouco importa, disposto a vencer, com aquela autodeterminação de aprender, de ser alguém, de elevar-se socialmente. Depois, com a morte do pai, humilde pintor de paredes, eis o molequinho escuro a ajudar a madrasta, 
com o tabuleiro de doces à cabeça, mas sempre encontrando folga para tomar as suas lições de francês com madame Gallot, dona de uma padaria em São Cristóvão. Um pouco mais crescido, surge o rapazinho a fazer amizade com o vigário, com quem poderia aprender alguma coisa a mais do que sabia. Mais tarde, trabalhando na loja de Paula Brito, vejo-o procurando se aproximar dos fregueses mais ilustrados captando a simpatia e conquistando a estima, já nessa época, com toda a certeza, do advogado Caetano Filgueiras e do padremestre Silveira Sarmento, que seriam, juntamente com Paula Brito e Manuel Antônio de Almeida, os padrinhos do jovem aspirante às letras.

"O dom que desde menino - observa Lúcia Miguel Pereira - Machado teve para atrair simpatias, dom estranho num gago, e num temperamento tão fechado, viria certamente da sua doçura de maneiras, da sensibilidade que sempre forcejou por esconder, mas que foi, nesse racionalista, um claro e forte penhor de generosidade, e da sua completa ausência de inveja." Machado de Assis venceria também a gagueira, tornando-se admirável causeur e até orador, quando as circunstâncias o impunham, ainda que conservando pequenos embaraços de pronúncia que dão, em determinados casos, um certo quê de simpatia à conversa dos gagos. Uma anedota muito repetida garante-nos que ele jamais conseguiria ir até o fim ao enunciar o comprido título do ilustre barão de Paranapiacaba. Tropeçava sempre na quarta sílaba do onomástico: Paraná... pipi... Outra anedota, contada por Max Fleiuss, dá-nos a certeza, entretanto, de que o defeito só o afligia em momentos incontroláveis. Como no caso da gafe da atriz Ismênia dos Santos, que tanto se entusiasmara com a fluência verbal do escritor, ao lhe ser apresentada:

- Ora veja, seu Machado - dissera-lhe no auge do entusiasmo tinham me dito que o senhor era tão gago, e entretanto fala muito bem!

Ao que lhe retrucou Machado de Assis, sabe Deus com quantos engasgos na língua, sem poder conter a sua irritabilidade nervosa:

- Ca... lúnias, minha senhora, ca... ca... lúnias...

A verdade é que, pelo seu trato afável, e principalmente pela sua capacidade de bem conversar, bons e fiéis amigos faria desde a primeira mocidade, e todos ou quase todos de condição social superior à sua: Sizenando Nabuco, filho de senador e conselheiro do Império, como José de Alencar; Francisco Otaviano, genro de fazendeiro rico, integrado na aristocracia rural de onde provinha Pedro Luís; Artur Napoleão, gênio precoce, grande músico, por todos adulado, não era aristocrata de sangue nem de dinheiro, mas de espírito, como também o era Quintino Bocaiuva; e 
ainda: Ramos Paz e Ernesto Cybrão, futuros capitalistas e comendadores, gente bem, gente fina. De todos esses amigos da mocidade, Otaviano, Quintino e talvez Henrique César Muzzio seriam, pela origem, os menos afortunados. Mesmo assim, em posição bem superior à de Machado de Assis. Além disso, Quintino e Muzzio eram brancos.

Quanto a Francisco Otaviano de Almeida Rosa, advogado e jornalista de prestígio, trata-se de um dos casos mais representativos de mimetismo racial, tão frequente naquela fase do Brasil Império, descrito e explicado com gosto literário e rigor científico por um escritor e professor da categoria de Gilberto Freyre, ao tratar do fenômeno sociológico que chamou da ascensão do bacharel e do mulato. Fenômeno social que fez surgir o mulato disfarçado, "mulatos cor de rosa, alguns louros, olhos azuis, podendo passar por brancos em lugares onde não soubessem direito as suas origens". À proporção que subiam na escala social, envergando o fraque e a sobrecasaca, cartola ou chapéu de feltro, colete de ramagens, gravata croisée, esses mulatos completavam a sua transferência, sociologicamente falando, de "pretos" para "brancos". Seriam incapazes de se reconhecerem mestiços, como o advogado Rebouças, que proclamou, com orgulho, na Câmara dos Deputados, ser ali o representante da população mulata do Brasil.

O velho Rebouças e os filhos, os dois irmãos Rebouças, grandes engenheiros que tantos serviços prestaram ao Brasil, jamais tentaram encobrir as raízes africanas dos seus troncos familiares, mas é bem possível que aos seus descendentes não agrade recordar essas origens. No próprio caso de Machado de Assis, acredito que a desenvoltura com que aludimos à sua cor e mesmo à sua origem humilde se deve principalmente ao fato de o escritor ilustre não ter deixado dois ou três herdeiros - bastaria um só, com certeza "branco", tal como a mãe portuguesa - dispostos a defender a pureza de sangue da família...

Não há negar que no Brasil de hoje, tido e havido como padrão talvez único de democracia racial, muita gente se sentirá estarrecida ao verificar os nomes da extensa lista de mestiços ilustres, apresentada pelo eminente dr. Silva Melo, no seu recente livro, Estudos sobre o negro, mestiços que alcançaram renome (alguns universal), nas artes, na ciência e na política brasileira, desde o padre José de Anchieta ao poeta Jorge de Lima, passando pelo Aleijadinho, por Gonçalves Dias, por Carlos Gomes, por Cotegipe, Sales Torres Homem, Floriano, Nilo Peçanha e tantos outros. E Silva Melo omitiu nessa relação o nome de Tiradentes, mulato que quisera desposar certa moça 
em São João del Rei, revela o escritor mineiro Aires da Mata Machado Filho, "opondo-se o pai da mesma por ser o pretendente colono e de cor morena".

A omissão de Tiradentes foi decerto involuntária, cochilo desculpável do mestre. Mas é muito possível que Silva Melo, para não ferir suscetibilidades, tenha feito deliberadamente outras omissões de ilustres brasileiros mortos e mesmo de vivos... Et pour cause...

É sintomático o exemplo de Roquette-Pinto, bonito homem, por quem todo mundo juraria não possuir nenhum resquício da raça condenada, e que, certa vez, confidenciara a Humberto de Campos:

Do que eu tenho, porém, certeza quase absoluta é de possuir nas veias sangue negro... Havia em casa um retrato de uma das minhas bisavós, que era o tipo clássico da mulata brasileira. Linda mulata! A nossa família não gostava que se dissesse isso. Mas quem fala aqui é o etnólogo, não é o membro da família.

$\mathrm{Na}$ voz dessa entidade, membro da família, as coisas mudam muitas vezes de sentido. Da viúva de Juliano Moreira, que era nascida na Alemanha, onde o mais ilustre dos nossos psiquiatras noivou e casou, ouvi a mais estranha das reações à indiscreta pergunta que lhe fiz numa entrevista de jornal, ao tocar, por dever de ofício, em assunto tão delicado: "O senhor está muito enganado. Meu marido não era preto, tampouco mulato. Para mim, desde que o vi, pela primeira vez, ele sempre me pareceu um príncipe hindu"...

Sem parecer hindu, mas parecendo ser um príncipe, na elegância do vestir e na distinção de maneiras, serviu o nosso Francisco Otaviano de Almeida Rosa como um dos modelos em que se inspiraria certamente Machado de Assis na sua ascensão social, ou com a propriedade técnica de expressão de Gilberto Freyre: na sua transferência de "preto" para "mulato". Ainda nesse ponto da acomodação do escritor na vida da sociedade do seu tempo, ressalta o mito de Apolo. Operou-se a metamorfose, durante a ascensão social, facilmente comprovada no exame comparativo das fotografias - poucas, infelizmente - que conhecemos da mocidade, da maturidade e da velhice. Assim na fotografia da mocidade, onde aparece ainda sem usar um dos elementos do disfarce posterior - o pince-nez. Está à página 96 da quinta edição da biografia de Lúcia Miguel Pereira e está no frontispício do Ao redor de Machado de Assis, de R. Magalhães Júnior. Observem o cabelo ruim, a contornar a altiva cabeça do retrato. Cabelo crespo, possivelmente grosso. Nas fotos da maturidade, como a do Álbum, 
página 208 da quinta edição da biografia de Lúcia Miguel Pereira, o corte brosse-carrée da cabeleira antes rebelde e o pince-nez quase que fazem desaparecer o mestiço. Entretanto, o disfarce é completado pela barba à europeia que lhe esconde os lábios grossos e talvez (quem sabe) a assimetria facial comum aos epilépticos. Disfarce sutil, dado o uso generalizado da barba. Mas onde surge a prova dos nove é na comparação das duas fotografias tiradas por Henrique Bernardelli : uma, de perfil, sem retoque (página 320 da terceira edição do Machado de Assis desconhecido, de R. Magalhães Júnior); a outra, de frente, retocada no sentido de torná-lo branco insuspeito (página 211 do mesmo livro), fotografia modelo para o quadro a óleo que se encontra na sede da Academia Brasileira de Letras, no qual os traços negroides da fisionomia de Machado de Assis foram habilmente escamoteados. A própria estátua de Humberto Cozzo, no pórtico da Academia, deve ter sido trabalhada com a mesma preocupação: ocultar o mulatismo (até o nariz foi afilado...), mulatismo que se denuncia inapelavelmente na máscara mortuária (Exposição do Centenário de Machado de Assis, edição do Instituto Nacional do Livro, 1939).

Que o escritor ocultava o seu mulatismo é mais do que evidente. Há de ter razão Lúcia Miguel Pereira ao asseverar que ele "não gostava de ouvir alusões à sua cor. Se não é verdade, como geralmente se diz, que nunca empregou nos seus livros a palavra mulato - em 'Pai contra mãe' repete-a várias vezes -, é certo que não lhe agradava ouvi-la em conversa."

Mais ainda: em nenhum dos seus livros, contos, romances, crônicas, artigos, aludiu ao problema da discriminação racial. Não quis enfrentá-lo. Esqueceu-o. Mas isso, santo Deus, não é nenhum crime, mesmo porque essa omissão deliberada não o transformou num monstro reacionário, num renegado infeliz da própria raça. Raimundo Magalhães Júnior, que tanta ênfase imprime às atitudes políticas de Machado de Assis, carregando nas tintas, na defesa de um ponto de vista ousado e por certo discutível, acertou em cheio ao apresentar a farta e preciosa contribuição com que esclarece o papel do escritor à frente da Diretoria de Agricultura, na interpretação do regulamento da Lei do Ventre Livre, relativamente à matrícula de escravos. Ao parecer ou pareceres de Machado de Assis, que depois firmariam jurisprudência sobre o assunto, mostra documentadamente o mais ativo dos pesquisadores atuais da vida e da obra do grande escritor, milhares de escravos tiveram a sua liberdade antecipada ao 13 de Maio.

O que não fez, nem faria, porque seria uma violência inútil contra a sua própria natureza, foi transformar-se num propagandista feroz do tipo de 
José do Patrocínio, temperamento explosivo de demagogo, e que por isso mesmo não pôde compreender a posição aparentemente absenteísta do escritor. Cada qual luta na vida, a seu modo, como pode, e com as armas que Deus lhe dá. A atitude de Machado de Assis, sempre tão discutida, em relação aos negros, acaba de ser lucidamente interpretada pelo ensaísta norte-americano Raymond S. Sayers em páginas de perfeita compreensão, ao analisar o espírito do romance machadiano, de condenação da sociedade escravocrata na qual se havia integrado. "Machado de Assis", diz ele:

não concordou com a escravidão e sentiu que os seus efeitos sobre a sociedade brasileira eram nocivos. Todavia, embora louvasse os romances e as peças antiescravistas, nas suas críticas literárias, ele próprio não tentou produzir obras de propaganda, pois o tipo de romance em que poderia melhor exprimir-se dificilmente poderia servir aos fins da campanha antiescravista. Não escreveu muito sobre os negros, como não o fez sobre as classes inferiores do Rio, porque só podia ilustrar seus temas sobre a pequenez essencial da natureza humana fazendo seus personagens os membros das classes superiores, gente que não tinha imaginação suficiente para usar da sua posição econômica privilegiada como meio para obter a liberdade espiritual.

Pelo seu feitio e temperamento, como pela educação, cada vez mais aprimorada, no processo de acomodação à sociedade, que assegurou a sua ascensão, Machado de Assis não assumiria nenhuma posição extremada. Nem o gesto quixotesco de um Antônio Pereira Rebouças, na fase agitadamente republicana da Regência, muito menos o protesto de um Lima Barreto, nas primeiras décadas da República.

Atitude agressiva a do romancista do Recordações do escrivão Isaías Caminha, ao proclamar o seu "negrismo", com que pretendia iniciar uma nova escola literária, para se revestir de um trágico acento masoquista, no final da vida, fazendo questão de aparecer sujo e maltrapilho na rua do Ouvidor. O mulato bêbedo tinha um estranho prazer de se mostrar miserável como um protesto vivo à sociedade burguesa. Tudo às avessas de Machado de Assis, embora ambos tivessem o seu complexo de cor: um, falando demais; o outro, de menos. O contraste é visível não apenas no comportamento social, podendo ser até representado na indumentária dos dois - Machado, bem composto, sempre irrepreensível no seu fraque; e Lima, com o seu esbodegado vestuário. Mas também na compreensão do fato literário - a serena acomodação de Machado de Assis aos cânones consagrados da língua 
e o ímpeto de Lima Barreto tentando quebrar as normas convencionais, antecipando-se de certo modo aos modernistas de 1922 e até mesmo aos romancistas do Nordeste de 1930 nos prenúncios de romance social que repontam na sua obra.

E nesse contraste mais uma vez aparece o mito de Apolo - que norteava Machado de Assis - em contraposição ao mito de Dionísio - que sempre marcou a personalidade e ação de Lima Barreto como escritor. Nietzsche assim define os dois estados de espírito: "No estado dionisíaco, todo o sistema emotivo está irritado e amplificado, de sorte que descarrega, num só golpe, todos os meios de expressão, arremetendo sua força de imitação, de reprodução, de transfiguração, de metamorfose, toda a espécie de mímica e de arte imitativa". Dionísio dá-nos a imagem da vida, o movimento, a paixão, o canto, a dança. É principalmente a força incontida. Apolo, ao contrário, conduz-nos a um ideal de perfeição, é a harmonia, o equilíbrio, a forma. É portanto a força contida, apurada, polida, dominada. A diferença entre um e outro está em que Lima Barreto foi vencido no seu assomo dionisíaco, ao passo que Machado de Assis saiu vencedor, com o seu apolinismo, não sem ter experimentado o "acre sabor" da vida, mas evitando que a vida se transformasse numa intolerável taça de fel.

É sem dúvida extraordinário que todos esses dons apolíneos se ajustem em homem tão sobrecarregado de condições negativas: a cor, a pobreza e sobretudo a doença, o mais terrível de todos os inimigos que teve pela frente e que o perseguiu, segundo parece, desde a infância. Pois à doença também se acomodaria, disfarçando-a quanto pôde tal como acontecera em relação à cor. Aos ataques, chamava "coisas esquisitas". Às feridas provocadas pelas mordeduras da língua, nas crispações violentas, preferia o eufemismo de designá-las como se fossem aftas. Sentia a proximidade das crises, recebia o aviso das manifestações, de sorte que só uma vez foi surpreendido em público com um ataque de epilepsia, que uma pungente fotografia documenta no livro de Peregrino Júnior, intitulado Doença e constituição de Machado de Assis.

Mas quem negará que foi essa tara maligna, acrescida do complexo de cor, que lhe deu força interior para levar até o fim a obra mais harmoniosamente construída de toda a literatura brasileira?

Quando a natureza é generosa, a satisfação dos sentidos como que relaxa a vontade dos indivíduos bem-dotados, anula o impulso criador, esteriliza-os, mata-os intelectualmente. A lei das compensações fez de Byron, lorde coxo, um grande poeta; do pré-tuberculoso Marcel Proust, antes um 
sibarita, um grande romancista. A mesma lei transformaria o promotor público Franklin Delano Roosevelt, atacado de paralisia infantil depois dos trinta anos, num grande estadista, numa das maiores figuras humanas do nosso tempo.

Pelas mesmas razões, foi a doença um dos fatores preponderantes do sucesso de Machado de Assis não somente como escritor mas como homem. É a doença, por incrível que pareça, a chave da convivência, o segredo da sua irradiação na sociedade. Teve muitos amigos, é verdade, mas não foi íntimo de nenhum deles, desviando o campo dos encontros para a rua. Em casa, não. Esta não servia nem para os jogos de xadrez, em que era mestre, nem para as tertúlias literárias, tão do seu agrado. Segundo a fórmula que ele mesmo inventou, referindo-se a um de seus personagens, era "pouco íntimo com os intimos".

O seu espírito associativo pode ser assim explicado como um eco do seu estado mórbido. Tornou-se, desde cedo, um campeão dos movimentos para a formação de clubes e sociedades literárias. A Petalógica, o Ensaios Literários, o Clube Beethoven, a Associação dos Homens de Letras e por fim a Academia Brasileira - sem falar nos cavacos à sombra das estantes da livraria Garnier, que eram um prolongamento das reuniões acadêmicas. Sei lá quantas sociedades ajudou a fundar ou delas participou, não como passivo associado mas como militante entusiasta. Enquanto procurava abrir tantos salões e ampliar os pontos de encontro, onde exercitava a camaradagem literária, fechava a porta da casa. Nada de intimidades, portanto, ainda que o conceito de intimidade seja, para muita gente, o mais elástico possível. Notadamente quando se pretende aparentar intimidade com pessoas importantes.

Machado de Assis nunca foi íntimo dos seus maiores amigos, nem os da mocidade, como Ramos Paz e Cybrão; nem os da maturidade, como Joaquim Nabuco e José Veríssimo; nem os da velhice, como Mário de Alencar e Carlos Magalhães de Azevedo. E por falar em intimidades, não resisto à tentação de recordar aqui a espirituosa referência de Gilberto Amado a homens que conseguem o milagre de não dar intimidade a ninguém, nem aos outros nem a si próprios. É o caso por exemplo de Epitácio Pessoa, glosado pelo ilustre escritor no quarto volume das suas memórias, Presença na política. Na biografia paterna, assim descreve a filha, dona Laurita Pessoa Raja Gabaglia, a chegada do ex-presidente da República a Petrópolis num fim de semana: "Ele chegava cansado do Rio e mudava o fraque pela roupa que sempre lhe pareceu a última palavra em matéria de conforto caseiro - terno de palha de seda, camisa dura, colarinhos e punhos engomados". E Gilberto Amado 
comenta com graça: "Para quem chegar em casa quer dizer camisa, sapatos, meias, cuecas, tudo fora do corpo, e acha robe de chambre ou pijama leve roupa demais - afigura-se incompreensível a falta de intimidade de Epitácio para consigo mesmo".

Decerto, Machado de Assis gozou da intimidade consigo mesmo, sem precisar andar nu dentro de casa, mas debruçado sobre o insondável da sua própria natureza, retratando-se, explicando-se, justificando-se, vingando-se através dos personagens que ia criando. E foi dessa assídua e prolongada intimidade que nasceu e tomou corpo a sua obra de romancista introspectivo, de dissecador às vezes implacável da alma humana. "É preciso não esquecer", lembra ainda Lúcia Miguel Pereira,

de que havia nele, a par da reserva, alguma coisa de gregário. Toda a vida procurou apoio nos pequenos grupos. Escritor, buscou as associações literárias, seguindo aliás uma tendência do seu tempo. Funcionário, devia-se ter querido enquadrar no elemento oficial, governista. E isso tudo sem ser íntimo dos companheiros de letras, nem pôr a pena ao serviço do governo. Encostava-se, sem abraçar.

E esclarece a biógrafa sempre exata e compreensiva:

Um psiquiatra veria sem dúvida nessa atitude uma manifestação típica da luta dos dois temperamentos mórbidos que se chocavam nele, o do introvertido e o do epiléptico. A introversão o levava a se fechar, mas a epilepsia o fazia sempre pronto a aderir ao grupo mais próximo, obrigando-o a um inconsciente mimetismo.

Trabalhador, que jamais se sentiria fatigado ou saciado da volúpia de trabalhar, dos dezesseis aos cinquenta e oito anos nunca deixou de colaborar regularmente na imprensa. Encanecido, entendeu de aprender alemão, como se tudo fosse recomeçar de novo. E quando, no governo de Prudente de Morais, por força da reforma havida no Ministério da Viação e Obras Públicas, foi posto em disponibilidade, embora sem prejuízo de um tostão em seus vencimentos, não descansou enquanto não voltou à atividade, na sua banca de burocrata, como Diretor Geral da Contabilidade, cargo que exerceu até a morte. Assim era o homem Machado de Assis. Tirar-lhe a obrigação de rotina era o mesmo que tirar-lhe a vida. Isso porque ao trabalho, quer na repartição, quer na sua mesa de escritor, entregava-se por inteiro, esquecido da doença, esquecido de tudo. 
Assim foi até o fim. Fiel consigo mesmo. Até mesmo depois da morte de dona Carolina, a quem ia levar, todos os domingos, um punhado de rosas com que cobria a sua sepultura. Discretamente, sem atrair a atenção dos transeuntes, tomava o bonde de Real Grandeza a caminho do cemitério com o seu embrulho de flores. "Levava-as embrulhadas - conta Lúcia Miguel Pereira - ou para não as desfolhar o vento, ou para não revelar aos outros o motivo da peregrinação". Nada impedia àquele velhinho de cumprir a sua devoção - a única que teve realmente na vida, além da literatura - nem mesmo a implicância do condutor de bonde, cumpridor do regulamento da Light, proibindo o porte de embrulhos nos carros de primeira classe. Nas suas visitas semanais ao São João Batista, passou o grande escritor a utilizarse dos carros de segunda, que a irreverência dos cariocas apelidou de "taiobas", não sei se desde aquele tempo.

Nada há de extraordinário nessa constante devoção em quem primava por conservar o travesseiro da esposa morta no leito irremediavelmente mutilado e o talher à mesa outrora comum da sala de jantar, no centro da sólida mobília de carvalho, em estilo Fontenebleau, tudo arrumado como se a dona da casa fosse aparecer a qualquer momento. Não era possível esquecer Carolina. Ela continuava a viver no chalé de Cosme Velho, e de tudo participava em espírito, como no jantar de noivado da afilhada com o tenente Estevão Leitão de Carvalho, hoje o ilustre general Leitão de Carvalho, a quem peço licença para reproduzir aqui as palavras nunca esquecidas do brinde, a emoção com que foram proferidas, diante do lugar vazio à outra cabeceira da mesa, mas que o prato e os talheres intocados denunciavam a presença invisível.

Levantando a taça de champanha, e como que se dirigindo também à Carolina, disse Machado de Assis:

Nós, brasileiros, consideramos as borboletas com o símbolo da inconstância, da leviandade. Os japoneses são mais observadores. Consideram as borboletas com o símbolo da fidelidade. Voam de flor em flor, é certo, mas aos pares. É o que desejo para vocês dois. Sejam como as borboletas, voando de flor em flor, mas sempre juntos.

Repetiu o mestre, nessa noite de fevereiro de 1904, uma velha imagem que retirou das páginas do Quincas Borba: "Um casal de borboletas, - que os japões têm por símbolo da fidelidade, por observarem que, se pousam de flor 
em flor, andam quase sempre aos pares"... Mas o seu pensamento estava todo voltado para Carolina e a sua própria felicidade conjugal. ${ }^{1}$

Um velhinho conduzindo um ramo de flores ao cemitério - é esta a derradeira imagem do homem Machado de Assis, por certo a mais comovente com o seu halo romântico, a ressaltar contudo a mesma firmeza, a mesma determinação, a mesma seriedade, na dura resposta com que, na véspera da morte, recusa a presença de um sacerdote ao seu leito de enfermo desenganado:

- Não creio... Seria uma hipocrisia...

$\mathrm{Na}$ hora suprema, arrancaria todos os disfarces. Quebraria todas as convenções, revelando-se por inteiro, como nos traços ancestrais que despontam da sua máscara mortuária.

O homem também era autêntico, tal como o escritor, expoente de uma plêiade de intelectuais que constituiu o núcleo fundador da Academia Brasileira de Letras. Expoente de uma geração que sob muitos aspectos revigorou o movimento de ideias no Brasil.

Graças à sua influência, não se formaria uma Academia com exclusões odiosas, motivadas por diferenças de ordem filosófica, social, ou simplesmente mundanas. Ali se congregaram as mais desencontradas tendências da nossa cultura, na época, os matizes mais diversos da coloração política, poderosos e decaídos. Racionalistas, livres-pensadores, como Sílvio Romeno, Araripe Júnior e Inglês de Sousa, ao lado de católicos ultramontanos, como Joaquim Nabuco, Carlos de Laet e J. M. Pereira da Silva. Monarquistas ferrenhos que pregavam abertamente a restauração do trono, como Eduardo Prado, Afonso Celso e de novo Nabuco, em companhia de republicanos de papo verde-e-amarelo, um Medeiros e Albuquerque, um Luís Murat, um Lúcio de Mendonça, este mais do que republicano socialista confesso. Quase socialista, de ideias bastante avançadas, era também um José Veríssimo. Os luminares da poesia, como Raimundo Correia, Bilac, Alberto de Oliveira. Os luminares do romance, Aluísio Azevedo, Coelho Neto. Os grandes publicistas e juristas, João Ribeiro, Rui Barbosa, Clóvis Beviláqua, Rodrigo Otávio, Sousa Bandeira. Grandes expressões da diplomacia, em paz ou em luta com o governo, como Salvador de Mendonça e Oliveira Lima.

Todos estavam ali contemplados, até os jovens, como Graça Aranha e Carlos Magalhães de Azevedo. Titulares do Império, ainda ostentando os seus brasões, como o barão de Loreto e o visconde de Taunay, de mãos dadas

\footnotetext{
${ }^{1}$ Em 1959, o casal Leitão de Carvalho festejará as bodas de ouro, cinquenta anos da mais perfeita felicidade conjugal.
} 
com um plebeu, o filho da quitandeira Justina: José do Patrocínio, nascido na pobreza, homem de cor, tal como o líder de todos esses intelectuais, Joaquim Maria Machado de Assis.

Nada mais restaria ao moleque do morro do Livramento, na sua maravilhosa ascensão social, de humilde proletário a primus inter pares da cultura brasileira. Do alto daquelas culminâncias, viveu Machado de Assis o mito de Apolo, tão completamente quanto seria possível. 